\title{
CHEMICAL STUDIES IN HYPERTENSION. REDUCING AND NITROGENOUS FRACTIONS IN PROTEIN-FREE BLOOD FILTRATES
}

\author{
BY RAYMOND F. HOLDEN, JR. \\ (From the Department of Internal Medicine, Washington University School of Medicine, \\ Saint Louis)
}

(Received for publication August 21, 1943)

The literature concerning non-glucose reducing substances in the blood in clinical states involving vascular hypertension has apparently been limited to observations incidental to other problems. In 1925 , certain investigators (1) found some increase in the non-glucose reducing fraction of zinc hydroxide (Hagedorn-Jensen) blood filtrates from patients with glomerulonephritis, some of whom presumably had hypertension. In 1927, Somogyi (2) noted an increase of reducing nonsugars in tungstic acid filtrates from patients with high nitrogen retention. Other authors (3), in 1929 , reported significant amounts of non-fermentable reducing substance in mercury filtrates from 2 patients with advanced hypertensive disease.

This report describes primarily the determination of non-fermentable reducing substance and non-urea nitrogen in protein-free blood filtrates from hypertensive subjects. The patients are classified into 2 groups, one with normal, the other with elevated blood non-protein nitrogen levels, in an effort to demonstrate any corresponding variations in the fractions under consideration.

\section{EXPERIMENTAL PROCEDURE}

Blood for analysis was drawn into flasks containing sodium oxalate as anticoagulant. Deproteinization and analysis were performed promptly. Some filtrates were stored overnight in stoppered bottles, in a cold room at 3 to $4^{\circ} \mathrm{C}$., pending analysis. This did not appear to affect the results in any way. Most of the blood samples were obtained under fasting conditions. Urea clearances were determined by a method described in 1928 (4). Mean blood pressures were recorded.

\section{ANALYTICAL METHODS}

Zinc hydroxide precipitation was performed according to Somogyi (2). Tungstic acid precipitation was carried out by the Folin and Wu (5) technic, as modified. by Haden (6). These methods were selected because of their convenience for the study of reducing and nitro- genous fractions. Tungstic acid filtrates contain apparently maximum amounts of these fractions, which are considerably restricted in zinc filtrates, by removal of glutathione, ergothionine, uric acid, etc. Non-protein nitrogen was determined by the method of Folin and $\mathrm{Wu}$ (5), by use of superoxol to clear the digestion mixtures when necessary. Urea nitrogen was estimated by the gasometric hypobromite method of Van Slyke and Kugel (7). Total reducing substance was determined with the copperiodometric reagent of Shaffer and Somogyi (8), containing 5 grams of potassium iodide per liter. For nonfermentable reducing substance, a reagent containing 1 gram of potassium iodide per liter was employed. Glucose was removed with washed yeast (Fleischmann's starch-free baker's yeast) by the method of Somogyi (2). All analyses were made in duplicate.

Values for non-fermentable reducing substance have been given in terms of glucose-equivalents, and therefore have only relative significance. The limits of error in the analytical method employed for estimating this fraction were found to be less than $1 \mathrm{mgm}$. of glucose per. $100 \mathrm{cc}$.

\section{RESULTS}

Table I presents the results on analysis of zinc filtrates from the control subjects. The ranges of non-protein nitrogen and urea are within the limits given by Somogyi (2) and by Peters and Van Slyke (9). The analytical results for nonfermentable reducing substance are in fair agreement with those given by Somogyi (2), there being no appreciable amount in 17 out of 21 filtrates.

Table II contains the findings on analysis of zinc filtrates from a group of hypertensive subjects with blood non-protein nitrogen below $30 \mathrm{mgm}$. per $100 \mathrm{cc}$. The range of the nitrogen fractions is very close to that in Table I. Appreciable nonfermentable reducing substance is present in 20 out of 27 filtrates. In 13 instances, the amount is greater than that found in any control filtrate.

Table III gives analytical data on zinc filtrates from a group of hypertensive subjects with blood 
TABLE I

Observations on zinc filtrates from control subjects

\begin{tabular}{|c|c|c|c|c|c|c|c|c|c|}
\hline \multirow{2}{*}{ Subject } & \multirow{2}{*}{ Age } & \multirow{2}{*}{ Diagnosis } & \multirow{2}{*}{$\begin{array}{c}\text { Blood } \\
\text { pressure }\end{array}$} & \multirow{2}{*}{$\begin{array}{l}\text { Urea } \\
\text { clear- } \\
\text { ance }\end{array}$} & \multirow{2}{*}{ N P N } & \multirow{2}{*}{ Urea $\mathbf{N}$} & \multirow{2}{*}{$\begin{array}{l}\text { Non- } \\
\text { urea. } \\
\text { N P N }\end{array}$} & \multicolumn{2}{|c|}{$\begin{array}{l}\text { Reducing substances, } \\
\text { estimated as glucose }\end{array}$} \\
\hline & & & & & & & & Total & $\begin{array}{c}\text { Non- } \\
\text { fermentable }\end{array}$ \\
\hline $\begin{array}{l}1 \\
2\end{array}$ & $\begin{array}{c}\text { years } \\
21 \\
35\end{array}$ & $\begin{array}{l}\text { Acute lead poisoning, latent syphilis, } \\
\text { secondary anemia } \\
\text { Diabetes mellitus, } 40 \text { units insulin }\end{array}$ & $\begin{array}{l}124 / 80 \\
115 / 80\end{array}$ & $\begin{array}{c}\text { per cent } \\
\text { of normal }\end{array}$ & \begin{tabular}{|c|} 
mgm. per \\
$100 \mathrm{cc.}$ \\
24
\end{tabular} & \begin{tabular}{|c|} 
mgm. per \\
100 cc. \\
10 \\
13
\end{tabular} & \begin{tabular}{|c|} 
mgm. per \\
$100 \mathrm{cc}$. \\
14
\end{tabular} & \begin{tabular}{|c|} 
mgm. per \\
100 cc. \\
92 \\
84
\end{tabular} & $\begin{array}{c}\text { mgm. per } \\
100 \text { cc. } \\
0 \\
0\end{array}$ \\
\hline $\begin{array}{c}3 \\
4 \\
5 \\
6 \\
7 \\
8 \\
9 \\
10 \\
11 \\
12 \\
13 \\
14 \\
15 \\
16 \\
17 \\
18 \\
19 \\
20 \\
21 \\
\text { Mean }\end{array}$ & $\begin{array}{l}18 \\
26 \\
40 \\
50 \\
34 \\
19 \\
24 \\
17 \\
27 \\
18 \\
18 \\
41 \\
59 \\
37 \\
23 \\
23 \\
24 \\
22 \\
27 \\
29\end{array}$ & $\begin{array}{l}\text { Saily } \\
\text { Subacute appendicitis } \\
\text { Rheumatic heart disease } \\
\text { Bronchial asthma } \\
\text { Diabetes mellitus } \\
\text { Acute salpingitis } \\
\text { Gigantism, traumatic ulcer } \\
\text { Healthy } \\
\text { Allergic eczema } \\
\text { Healthy } \\
\text { Peptic ulcer } \\
\text { Sacro-iliac strain } \\
\text { Chronic sinusitis, chronic cholecystitis } \\
\text { Allergic dermatitis } \\
\text { Healthy } \\
\text { Bronchial asthma } \\
\text { Healthy } \\
\text { Acute tonsillitis, rheumatic arthritis } \\
\text { Healthy } \\
\text { Gonorrheal arthritis }\end{array}$ & $\begin{array}{c}112 / 64 \\
140 / 20 \\
124 / 100 \\
126 / 86 \\
118 / 70 \\
140 / 80 \\
108 / 64 \\
124 / 88 \\
112 / 70 \\
122 / 82 \\
120 / 75 \\
124 / 80 \\
114 / 72 \\
125 / 75 \\
95 / 70 \\
112 / 70 \\
130 / 86 \\
138 / 84 \\
150 / 88 \\
123 / 75\end{array}$ & $\begin{array}{r}118 \\
73 \\
127 \\
81 \\
108 \\
121 \\
109 \\
88 \\
111 \\
132 \\
82 \\
83 \\
99 \\
116 \\
95 \\
110 \\
103\end{array}$ & $\begin{array}{l}19 \\
33 \\
25 \\
21 \\
18 \\
20 \\
17 \\
19 \\
21 \\
19 \\
23 \\
26 \\
19 \\
22 \\
20 \\
20 \\
23 \\
18 \\
23 \\
22\end{array}$ & $\begin{array}{r}9 \\
19 \\
17 \\
13 \\
7 \\
11 \\
8 \\
12 \\
10 \\
10 \\
12 \\
17 \\
8 \\
11 \\
7 \\
12 \\
11 \\
8 \\
12 \\
11\end{array}$ & $\begin{array}{r}10 \\
14 \\
8 \\
8 \\
11 \\
9 \\
9 \\
7 \\
11 \\
9 \\
11 \\
9 \\
11 \\
11 \\
13 \\
8 \\
12 \\
10 \\
11 \\
10\end{array}$ & $\begin{array}{r}68 \\
75 \\
58 \\
222 \\
62 \\
86 \\
74 \\
50 \\
78 \\
68 \\
75 \\
60 \\
73 \\
78 \\
45 \\
88 \\
98 \\
82 \\
64 \\
80\end{array}$ & $\begin{array}{l}0 \\
0 \\
1 \\
0 \\
0 \\
2 \\
0 \\
0 \\
0 \\
0 \\
1 \\
0 \\
0 \\
0 \\
0 \\
0 \\
0 \\
0 \\
1 \\
0.2\end{array}$ \\
\hline $\begin{array}{l}\text { Standard } \\
\text { deviation }\end{array}$ & & & & \pm 16.6 & \pm 3.6 & \pm 3.2 & \pm 1.9 & \pm 34.3 & \pm 0.5 \\
\hline
\end{tabular}

non-protein nitrogen of $30 \mathrm{mgm}$. per $100 \mathrm{cc}$. and over. Corresponding to expectation, there is elevation of the non-urea nitrogen as compared with Tables I and II. Demonstrable amounts of non-fermentable reducing substance are present in 10 out of 11 filtrates, with a mean value more than double that in Table II. The difference between these means appears significant, since its probable error is $\pm 0.5 \mathrm{mgm}$. per $100 \mathrm{cc}$., or less than one-fourth of the difference.

There does not appear to be any correlation between the amounts of non-fermentable reducing substances shown in Tables II and III with blood pressures. The relation to urea clearances is uncertain. In Table III, the two highest values for non-fermentable reducing substance occur in subjects with clearances below 10 per cent of normal. With higher clearances, there does not appear to be any correlation. There is some tendency for non-urea nitrogen to vary with nonfermentable reducing substance, the correlation coefficients in Tables II and III being +0.26 and +0.30 , respectively.

Classification of the subjects in Tables II and III according to clinical diagnoses shows that appreciable amounts of non-fermentable reducing substance were present in each of 6 cases of malignant hypertension, with a mean value of 3.3 mgm. per $100 \mathrm{cc}$. (referred to glucose); in 15 out of 21 cases of benign hypertension, with a mean value of $1.9 \mathrm{mgm}$. per $100 \mathrm{cc}$; and in 4 out of 5 cases of arteriosclerosis with hypertension, with a mean value of $2.0 \mathrm{mgm}$. per $100 \mathrm{cc}$.

Tungstic acid filtrates from groups of control and hypertensive subjects without nitrogen retention were analyzed in a similar way. The mean values for non-protein nitrogen in the two groups were almost identical : $24.9 \mathrm{mgm}$. per 100 cc. for the controls, $24.8 \mathrm{mgm}$. per $100 \mathrm{cc}$. for the hypertensives. The mean value for non-fermentable reducing substance in the control group was $20.9 \mathrm{mgm}$. per $100 \mathrm{cc}$., in close agreement with 
the figure of $21 \mathrm{mgm}$. per $100 \mathrm{cc}$. given by Somogyi (2). A mean value of $22.3 \mathrm{mgm}$. per $100 \mathrm{cc}$. was obtained in the hypertensive group. The variation within the groups was such as to tend to obscure the significance of any difference between the means.

A few preliminary experiments were made relative to the non-fermentable reducing substance present in zinc filtrates from subjects with hypertension. It appeared to be stable on storage in the cold and to reside chiefly in the plasma. Attempts at acid hydrolysis of filtrates resulted in little or no change in the amount of non-fermentable reducing substance.

\section{DISCUSSION}

As suggested by Hiller, Linder, and Van Slyke (1), it is entirely possible that retained nitrogenous substances, such as uric acid and creatinine, may account for abnormal reducing properties in appropriate blood filtrates. Somogyi (2) found that zinc filtrates of blood from normal subjects prepared by his method contain somewhat less creatinine than tungstic acid filtrates and are free from uric acid, glutathione, and ergothionine. The nature of the non-urea nitrogen and nonfermentable reducing substance in these filtrates remains largely unknown. Retention of crea-

TABLE $\mathbf{n}$

Observations on ainc filtrates from hypertensive subjects with non-protein nitrogen below $30 \mathrm{mgm}$. per $100 \mathrm{cc}$.

\begin{tabular}{|c|c|c|c|c|c|c|c|c|c|}
\hline \multirow{2}{*}{ Subject } & \multirow{2}{*}{ Age } & \multirow{2}{*}{ Diagnosis } & \multirow{2}{*}{$\begin{array}{c}\text { Blood } \\
\text { pressure }\end{array}$} & \multirow{2}{*}{$\begin{array}{l}\text { Urea } \\
\text { clear- } \\
\text { ance }\end{array}$} & \multirow{2}{*}{ N P N } & \multirow{2}{*}{ Urea $\mathbf{N}$} & \multirow{2}{*}{$\begin{array}{c}\text { Non- } \\
\text { urea } \\
\text { N P N }\end{array}$} & \multicolumn{2}{|c|}{$\begin{array}{l}\text { Reducing substances, } \\
\text { estimated as glucose }\end{array}$} \\
\hline & & & & & & & & Total & $\underset{\text { fermentable }}{\text { Non- }}$ \\
\hline 22 & $\begin{array}{l}\text { years } \\
33\end{array}$ & $\begin{array}{l}\text { Essential hypertension, hyp. ht. dis., } \\
\text { chr. bronchitis }\end{array}$ & $190 / 110$ & \begin{tabular}{|} 
per cent \\
of normal \\
80
\end{tabular} & \begin{tabular}{|}
$\mathrm{mgm}$. per \\
$100 \mathrm{cc.}$ \\
21
\end{tabular} & \begin{tabular}{|} 
mgm. per \\
100 cc. \\
8
\end{tabular} & $\begin{array}{l}\text { mgm. per } \\
100 \text { cc. } \\
13\end{array}$ & \begin{tabular}{|} 
mgm.per \\
100 cc. \\
80
\end{tabular} & $\begin{array}{l}\operatorname{mgm} . \text { per } \\
100 \text { cc. } \\
5\end{array}$ \\
\hline $\begin{array}{l}23 \\
24 \\
25\end{array}$ & $\begin{array}{l}44 \\
50 \\
54\end{array}$ & $\begin{array}{l}\text { Essential hypertension, hyp. ht. dis. } \\
\text { Essential hypertension, hyp. ht. dis. } \\
\text { Essential hypertension, hyp. encepha- } \\
\text { lopathy }\end{array}$ & $\begin{array}{l}155 / 105 \\
268 / 140 \\
190 / 108\end{array}$ & $\begin{array}{r}85 \\
79 \\
103\end{array}$ & $\begin{array}{l}26 \\
18 \\
22\end{array}$ & $\begin{array}{l}17 \\
10 \\
12\end{array}$ & $\begin{array}{r}9 \\
8 \\
10\end{array}$ & $\begin{array}{r}84 \\
178 \\
79\end{array}$ & $\begin{array}{l}1 \\
0 \\
4\end{array}$ \\
\hline $\begin{array}{l}26 \\
27 \\
28 \\
29\end{array}$ & $\begin{array}{l}47 \\
21 \\
54 \\
37\end{array}$ & $\begin{array}{l}\text { Essential hypertension, hyp. ht. dis. } \\
\text { Malignant hypertension } \\
\text { Essential hypertension } \\
\text { Essential hypertension, hyp. ht. dis., } \\
\text { thyroidectomy }\end{array}$ & $\begin{array}{l}178 / 98 \\
220 / 118 \\
168 / 98 \\
218 / 110\end{array}$ & $\begin{array}{l}79 \\
84 \\
92 \\
77\end{array}$ & $\begin{array}{l}24 \\
21 \\
20 \\
21\end{array}$ & $\begin{array}{l}12 \\
12 \\
12 \\
11\end{array}$ & $\begin{array}{r}12 \\
9 \\
8 \\
10\end{array}$ & $\begin{array}{r}78 \\
148 \\
143 \\
54\end{array}$ & $\begin{array}{l}0 \\
2 \\
1 \\
1\end{array}$ \\
\hline $\begin{array}{l}30 \\
31\end{array}$ & $\begin{array}{l}52 \\
33\end{array}$ & $\begin{array}{l}\text { Essential hypertension } \\
\text { Malignant hypertension, lt. lumbar } \\
\text { sympathectomy }\end{array}$ & $\begin{array}{l}190 / 130 \\
174 / 110\end{array}$ & $\begin{array}{r}126 \\
97\end{array}$ & $\begin{array}{l}26 \\
17\end{array}$ & $\begin{array}{r}14 \\
8\end{array}$ & $\begin{array}{r}12 \\
9\end{array}$ & $\begin{array}{l}99 \\
87\end{array}$ & $\begin{array}{l}2 \\
4\end{array}$ \\
\hline $\begin{array}{l}32 \\
33 \\
34 \\
35 \\
36 \\
37 \\
38\end{array}$ & $\begin{array}{l}39 \\
54 \\
66 \\
35 \\
46 \\
35 \\
49\end{array}$ & $\begin{array}{l}\text { Essential hypertension, hyp. ht. dis. } \\
\text { Arteriosclerosis with hypertension } \\
\text { Essential hypertension, hyp. ht. dis. } \\
\text { Malignant hypertension, CNS syphilis } \\
\text { Arteriosclerosis with hypertension } \\
\text { Essential hypertension, hyp. ht. dis. } \\
\text { Essential hypertension, diabetes, } \\
\text { obesity, goiter }\end{array}$ & $\begin{array}{l}220 / 100 \\
264 / 130 \\
185 / 90 \\
220 / 130 \\
176 / 110 \\
176 / 100 \\
204 / 114\end{array}$ & $\begin{array}{r}96 \\
171 \\
90 \\
80 \\
85 \\
87\end{array}$ & $\begin{array}{l}17 \\
20 \\
17 \\
23 \\
25 \\
18 \\
19\end{array}$ & $\begin{array}{r}10 \\
8 \\
8 \\
14 \\
13 \\
7 \\
9\end{array}$ & $\begin{array}{r}7 \\
12 \\
9 \\
9 \\
12 \\
11 \\
10\end{array}$ & $\begin{array}{r}150 \\
43 \\
82 \\
106 \\
62 \\
89 \\
57\end{array}$ & $\begin{array}{l}1 \\
3 \\
3 \\
1 \\
1 \\
1 \\
0 \\
0\end{array}$ \\
\hline $\begin{array}{l}39 \\
40 \\
41 \\
42\end{array}$ & $\begin{array}{l}53 \\
39 \\
37 \\
28\end{array}$ & $\begin{array}{l}\text { Essential hypertension } \\
\text { Essential hypertension } \\
\text { Thyrotoxicosis, thyrotoxic ht. dis. } \\
\text { Malignant hypertension, hyp. enceph- } \\
\text { alopathy }\end{array}$ & $\begin{array}{l}210 / 115 \\
196 / 128 \\
181 / 85 \\
180 / 130\end{array}$ & $\begin{array}{r}157 \\
83 \\
133 \\
55\end{array}$ & $\begin{array}{l}19 \\
19 \\
20 \\
29\end{array}$ & $\begin{array}{r}8 \\
10 \\
8 \\
18\end{array}$ & $\begin{array}{r}11 \\
9 \\
12 \\
11\end{array}$ & $\begin{array}{r}132 \\
94 \\
72 \\
63\end{array}$ & $\begin{array}{l}\mathbf{3} \\
\mathbf{0} \\
\mathbf{3} \\
\mathbf{3}\end{array}$ \\
\hline $\begin{array}{l}43 \\
44\end{array}$ & $\begin{array}{l}58 \\
68\end{array}$ & $\begin{array}{l}\text { Essential hypertension, hyp. ht. dis. } \\
\text { Arteriosclerosis with hypertension, } \\
\text { hyp. ht. dis. }\end{array}$ & $\begin{array}{l}214 / 126 \\
200 / 110\end{array}$ & $\begin{array}{l}68 \\
68\end{array}$ & $\begin{array}{l}17 \\
22\end{array}$ & $\begin{array}{r}9 \\
13\end{array}$ & $\begin{array}{l}8 \\
9\end{array}$ & $\begin{array}{l}90 \\
87\end{array}$ & $\begin{array}{l}1 \\
0\end{array}$ \\
\hline $\begin{array}{l}45 \\
46 \\
47 \\
48\end{array}$ & $\begin{array}{l}66 \\
56 \\
62 \\
42\end{array}$ & $\begin{array}{l}\text { Essential hypertension, hyp. ht. dis. } \\
\text { Hyperthyroidism } \\
\text { Essential hypertension, hyp. ht. dis. } \\
\text { Essential hypertension }\end{array}$ & $\begin{array}{l}185 / 90 \\
200 / 104 \\
194 / 104 \\
170 / 120\end{array}$ & $\begin{array}{l}59 \\
45 \\
59 \\
63\end{array}$ & $\begin{array}{l}20 \\
24 \\
27 \\
18\end{array}$ & $\begin{array}{r}10 \\
16 \\
13 \\
6\end{array}$ & $\begin{array}{r}10 \\
8 \\
14 \\
12\end{array}$ & $\begin{array}{r}64 \\
112 \\
126 \\
107\end{array}$ & $\begin{array}{l}3 \\
2 \\
0 \\
3\end{array}$ \\
\hline Mean & 47 & & $197 / 112$ & 89 & 21 & 11 & 10 & 95 & 1.7 \\
\hline $\begin{array}{l}\text { Standard } \\
\text { deviation }\end{array}$ & & & & \pm 29.7 & \pm 3.4 & \pm 3.1 & \pm 1.8 & \pm 33.1 & \pm 1.5 \\
\hline
\end{tabular}


TABLE III

Observations on sinc filtrates from hypertensive subjects with non-protein nitrogen $30 \mathrm{mgm}$. per 100 ce. and over

\begin{tabular}{|c|c|c|c|c|c|c|c|c|c|}
\hline \multirow{2}{*}{ Subject } & \multirow{2}{*}{ Age } & \multirow{2}{*}{ Diagnosis } & \multirow{2}{*}{$\begin{array}{c}\text { Blood } \\
\text { pressure }\end{array}$} & \multirow{2}{*}{$\begin{array}{l}\text { Urea } \\
\text { clear- } \\
\text { ance }\end{array}$} & \multirow{2}{*}{ N P N } & \multirow{2}{*}{ Urea $\mathbf{N}$} & \multirow{2}{*}{$\begin{array}{c}\text { Non- } \\
\text { urea } \\
\text { N P N }\end{array}$} & \multicolumn{2}{|c|}{$\begin{array}{l}\text { Reducing substances, } \\
\text { estimated as glucose. }\end{array}$} \\
\hline & & & & & & & & Total & $\begin{array}{l}\text { Non- } \\
\text { fermentable }\end{array}$ \\
\hline $\begin{array}{l}49 \\
50 \\
51 \\
52 \\
53\end{array}$ & $\begin{array}{l}\text { yeers } \\
59 \\
45 \\
40 \\
57 \\
67\end{array}$ & $\begin{array}{l}\text { Arteriosclerosis with hypertension } \\
\text { Essential hypertension } \\
\text { Malignant hypertension } \\
\text { Malignant hypertension, hyp. ht. dis. } \\
\text { Essential hypertension, hyp. ht. dis., } \\
\text { cor. art. dis. }\end{array}$ & $\begin{array}{l}190 / 100 \\
190 / 125 \\
212 / 142 \\
260 / 160 \\
218 / 110\end{array}$ & \begin{tabular}{|c|} 
per cent \\
of normal \\
78 \\
19 \\
8 \\
48 \\
43
\end{tabular} & \begin{tabular}{|c|} 
mgm. per \\
100 cc. \\
36 \\
61 \\
84 \\
42 \\
36
\end{tabular} & \begin{tabular}{|c|} 
mgm. per \\
100 ce. \\
24 \\
42 \\
62 \\
31 \\
21
\end{tabular} & $\begin{array}{c}\text { mom. per } \\
100 \text { cc. } \\
12 \\
19 \\
22 \\
11 \\
15\end{array}$ & \begin{tabular}{|c|} 
mgm. per \\
100 cc. \\
78 \\
68 \\
66 \\
76 \\
100
\end{tabular} & $\begin{array}{l}\text { mgm. per } \\
100 \text { cc. } \\
3 \\
3 \\
7 \\
3 \\
4\end{array}$ \\
\hline $\begin{array}{l}54 \\
55 \\
56 \\
57 \\
58 \\
59\end{array}$ & $\begin{array}{l}62 \\
24 \\
58 \\
59 \\
28 \\
29\end{array}$ & $\begin{array}{l}\text { Essential hypertension, cor. art. dis. } \\
\text { Chronic hemorrhagic nephritis } \\
\text { Arteriosclerotic nephritis } \\
\text { Arteriosclerosis with hypertension } \\
\text { Chronic hemorrhagic nephritis, uremia } \\
\text { Pituitary basophilism? }\end{array}$ & $\begin{array}{l}220 / 98 \\
155 / 95 \\
180 / 120 \\
220 / 148 \\
220 / 115 \\
180 / 110\end{array}$ & $\begin{array}{r}59 \\
32 \\
24 \\
15 \\
4 \\
58\end{array}$ & $\begin{array}{r}30 \\
38 \\
45 \\
85 \\
135 \\
31\end{array}$ & $\begin{array}{r}22 \\
23 \\
35 \\
72 \\
118 \\
21\end{array}$ & $\begin{array}{r}8 \\
15 \\
10 \\
13 \\
17 \\
10\end{array}$ & $\begin{array}{r}101 \\
82 \\
94 \\
164 \\
73 \\
151\end{array}$ & $\begin{array}{l}5 \\
0 \\
3 \\
3 \\
8 \\
4\end{array}$ \\
\hline Mean & 48 & $\cdot$ & $204 / 120$ & 35 & 57 & 43 & 14 & 96 & 3.9 \\
\hline $\begin{array}{l}\text { Standard } \\
\text { deviation }\end{array}$ & & & & \pm 23.8 & \pm 32.6 & \pm 30.4 & \pm 4.3 & \pm 32.9 & \pm 2.2 \\
\hline
\end{tabular}

tinine might account for the larger amounts found in Table III, as compared with Table II. A slight association between these fractions is suggested by analysis of the data. The correlation is of a low order, however, and the tendency for non-fermentable reducing substance to appear before the non-protein nitrogen rises suggests that the former may contain little or no nitrogen under the conditions imposed. This would be in agreement with the observations of West, Scharles, and Peterson (3) on mercury filtrates, which were found to contain increased amounts of non-fermentable reducing substance in 2 cases of hypertensive disease, but were generally free from nitrogen.

It may be significant that the two highest values for non-fermentable reducing substance in zinc filtrates occurred in those from patients with urea clearances less than 10 per cent of normal. If the limited number of subjects and the variation inherent in the urea clearance are taken into account, the apparent absence of progressive accumulation of this reducing fraction with moderate decrease in renal function suggests that it is either readily excreted or destroyed under such conditions. The increase with severe renal damage might be interpreted to mean that it is eliminated largely via the kidneys,--perhaps by a mechanism analogous to that for urea, which does not tend to accumulate in the body fluids until its renal clearance has been lowered to less than half its usual value. This would be in agreement with the observation by West (10) that appreciable amounts of non-fermentable reducing substances are present in normal urine. West pointed out that the amount eliminated is related to the carbohydrate intake, and particularly to the ingestion of caramelized material. Whether this has any bearing on the nonfermentable reducing substance noted in the present study is a matter for investigation.

Attention is called to the possibility that reducing substances might tend to accumulate in the blood or urine by interference with renal oxidations. Glaser, Laszlo, and Schürmeyer (11) have shown that mammalian kidneys normally require up to 20 per cent of the total oxygen uptake. These investigators, confirmed by Van Slyke, Rhoads, Hiller, and Alving (12), report a linear relationship between renal blood flow and oxygen consumption, both of which are unrelated to excretory activity. Studies of hypertensive subjects by indirect methods, summarized recently by Foà, Woods, Peet, and Foà (13), indicate a fairly general tendency toward lowering of renal blood flow in these subjects. It would seem to follow, pari passu, that there might exist a corresponding tendency toward impairment of 
renal oxygen consumption. As a working hypothesis, it is suggested that renal ischemia, by interfering with intense cellular oxidations, may give origin to unusual amounts of incompletely oxidized substances. This hypothesis should be susceptible to direct experimental examination.

The preliminary examination of zinc filtrates containing non-fermentable reducing substance suggests that it is stable and exists chiefly in the plasma. This latter finding is in contrast with the studies of Somogyi (2) on tungstic acid filtrates, in which the bulk of the non-fermentable reducing fraction was shown to originate in the cells.

\section{SUMMARY}

1. Protein-free blood filtrates from subjects with and without arterial hypertension have been examined for non-fermentable reducing substance and non-urea nitrogen content.

2. Appreciable amounts of non-fermentable reducing substance were noted in 30 out of 38 zinc filtrates from patients with hypertensive disease, and in 4 out of 21 control filtrates. A similar difference was found in tungstic acid filtrates.

3. Among the hypertensive subjects, the nonfermentable reducing substance in zinc filtrates exhibited some tendency to vary with non-urea nitrogen. No direct relation to blood pressure or urea clearance could be demonstrated.

\section{BIBLIOGRAPHY}

1. Hiller, A., Linder, G. C., and Van Slyke, D. D., The reducing substances of the blood. J. Biol. Chem., $1925,64,625$.
2. Somogyi, M., Reducing non-sugars and true sugar in human blood. J. Biol. Chem., 1927, 75, 33; The distribution of sugar in normal human blood. Ibid., $1928,78,117$; A method for the preparation of blood filtrates for the determination of sugar. Ibid., 1930, 86, 655; Nitrogenous substances in zinc filtrates of human blood. Ibid., 1930, 87, 339.

3. West, E. S., Scharles, F. H., and Peterson, V. L., The determination of true sugar in blood. J. Biol. Chem., 1929, 82, 137.

4. Möller, E., McIntosh, J. F., and Van Slyke, D. D., Studies of urea excretion. II. Relationship between urine volume and the rate of urea excretion by normal adults. J. Clin. Invest., 1928, 6, 427.

5. Folin, O., and Wu, H., A system of blood analysis. J. Biol. Chem., 1919, 38, 81.

6. Haden, R. L., A modification of the Folin-Wu method for making protein-free filtrates. J. Biol. Chem., 1923, 56, 469.

7. Van Slyke, D. D., and Kugel, V. H., Improvements in manometric micro-Kjeldahl and blood urea methods. J. Biol. Chem., 1933, 102, 489.

8. Shaffer, P. A., and Somogyi, M., Copper-iodometric reagents for sugar determination. J. Biol. Chem., 1933, 100, 695.

9. Peters, J. P., and Van Slyke, D. D., Quantitative Clinical Chemistry. Vol. I. Interpretations. Williams and Wilkins, Baltimore, 1931.

10. West, E. S., Réducing substances in urine. J. Biol. Chem., 1931, 92, xxiv.

11. Glaser, H., Laszlo, D., and Schürmeyer, A., Uber den Energieumsatz der Niere. Arch. f. exper. Path. u. Pharm., 1932, 168, 139.

12. Van Slyke, D. D., Rhoads, C. P., Hiller, A., and Alving, A. S., Relationships between urea excretion, renal blood flow, renal oxygen consumption, and diuresis. The mechanism of urea excretion., Am. J. Physiol., 1934, 109, 336.

13. Foà, P. P., Woods, W. W., Peet, M. M., and Foà, N. L., Effective renal blood flow, glomerular filtration rate and tubular excretory mass in arterial hypertension. Arch. Int. Med., 1942, 69, 822. 